\title{
Enhancing Phenolic Maturity of Syrah with the Application of a New Foliar Spray
}

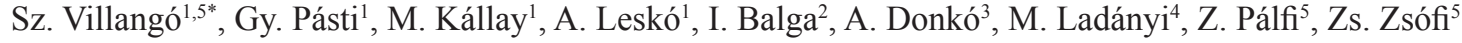

(1) Department of Oenology, Institute of Viticulture and Oenology, Corvinus University of Budapest, Budapest, Hungary

(2) Department of Chemistry, Wine Chemistry and Oenology, Institute of Food Sciences, Eszterházy Károly College, Eger, Hungary

(3) Department of Viticulture, Institute of Viticulture and Oenology, Corvinus University of Budapest, Budapest, Hungary

(4) Department of Biometrics and Agricultural Informatics, Corvinus University of Budapest, Budapest, Hungary

(5) KRC Research Institute for Viticulture and Oenology, Eger Kölyuktetö, P.O. Box 83, Eger, Hungary

Submitted for publication: March 2015

Accepted for publication: April 2015

Key words: Anthocyanin extractability, phenolic maturity, foliar spray, berry ripening, berry texture, resveratrol

\begin{abstract}
Climate change is inducing earlier grape ripening, especially in warm vintages. This phenomenon is resulting in unbalanced wines an alcohol concentration that is too high and titratable acidity that is low, along with a high $\mathrm{pH}$ level without the desired level of phenolic maturity. Final wine quality notably depends on the phenolic composition of the grapes and the extractability of these compounds. This research was designed to test a new foliar spray, called LalVigne ${ }^{\circledR}$ MATURE, for its capacity to create a balance between sugar development and phenolic maturity. It is a formulation of $100 \%$ natural, inactivated wine yeast derivatives. This foliar spray was tested on Syrah vines in two vintages (2012 and 2013) in a cool-climate wine region (Eger, Hungary). The spray acted as an elicitor, stimulating the synthesis of several secondary metabolites. The changes in anthocyanin extractability and texture characteristics of the grape berries were followed during ripening. Experimental wines were made at three separate harvest times in each vintage. Standard analytical parameters were evaluated for grapes and wines, as well as for resveratrol. Grapes from the treated vines had thicker skins than the controls at all sampling dates in both vintages. The phenolic potential (especially anthocyanin concentration and extractability) of the foliar spray-treated grapes was greatly improved. Our experiment showed that phenolic ripening can be enhanced using the foliar spray, and that its application was useful in different vintages.
\end{abstract}

\section{INTRODUCTION}

Nowadays, wine consumers prefer well-structured wines with deep colour, fruit scents, soft tannins and a pleasant mouthfeel (Bruwer et al., 2011). These kinds of wines can be made from well-ripened grapes with an optimal level of phenolic and technological (sugar) maturity, but not from over-ripened grapes. Nevertheless, the changing climate modifies the ripening process notably. In cool-climate wine regions, such as the Eger wine district in Hungary, we can count on more frequent extreme weather events, including uneven precipitation, heat waves and droughts (Schultz, 2000). In dry and hot vintages, the ripening process is faster and the balance between phenolic and technological (sugar) maturity may not be maintained (Hannah et al., 2013). This results in an increase in the sugar concentration and, in parallel, a rapid decrease in the titratable acidity, resulting in unbalanced wines that are too alcoholic. At the same time, the lack of optimal phenolic maturity results in wines with green and astringent tannins (Jones et al., 2005). On the other hand, the ripening is slowed in a rainy, cool vintage, and late ripening varieties (such as Cabernet Sauvignon, Cabernet Franc and Syrah) cannot reach optimal maturity (Jackson \& Lombard, 1993).

Several technological applications can be used in order to reduce these negative effects. Cluster thinning (Guidoni et al., 2002; Prajitna et al., 2007), girdling (Singh Brar et al., 2008; Koshita et al., 2011) and early defoliation (Poni et al., 2006; 2009; Kemp et al., 2011; Gatti et al., 2012; Lee \& Skinkis, 2013) are reported to have a beneficial effect on phenolic maturity, especially on anthocyanin and flavonoid synthesis. The resveratrol content of the grape varies considerably and depends on many viticultural factors, including climate, terroir, grape variety, fungal infections and yield (Jeandet et al., 1995; Bavaresco, 2003; Bavaresco

*Corresponding author: E-mail address: szvillango@szbki-eger.hu [Tel.: +36 37518 310]

Acknowledgements: This project was supported by TÁMOP grants (TÁMOP-4.2.2/B-10/1-2010-0023 and TÁMOP-4.2.1/B-09/1/KMR-2010-0005) from the European Union and the János Bolyai Postdoctoral Fellowship (Zsolt Zsófi). We would like to thank Lallemand Inc. and Kokoferm Ltd. for the foliar spray and yeast products used during the experiment. We also thank Gróf Buttler Winery for providing the experimental sites in its vineyard. The authors further wish to thank Ágnes Herczeg, Carlos Suárez Martinez, Karl Burger and Anthony Silvano, for their valuable advice, and Dr Geoffrey R. Scollary, Dr Fernando Zamora Marin and Dr Joan Miquel Canals, for their help in revising the manuscript 
et al., 2007; Prajitna et al., 2007). There are also some papers dealing with the increasing resveratrol concentration in grapes using elicitors (Vezzulli et al., 2007; Santamaria et al., 2011).

Beyond the above-mentioned techniques, a new foliar spray for enhancing phenolic maturity was developed recently and was examined for its effects. In addition, Syrah is a new cultivar to the Eger wine region, where there is only limited cultivation experience with it.

The aim of this study was to 1) describe the effects of the application of this new foliar spray on grape phenolic maturity and 2) describe some aspects of the responses of a "new" variety (Syrah, Vitis vinifera L.) in a cool-climate wine region (Eger, Hungary).

\section{MATERIALS AND METHODS \\ Description of the experimental site and the experimental design}

The experiment took place at Nagy-Eged hill, a commercial vineyard (lat. 47 $55^{\prime} 31.84^{\prime \prime} \mathrm{N}$; long. 20²4'42.32” W, elevation $430 \mathrm{~m}$ above sea level, asl) in the Eger wine region (northeast Hungary). The vineyard's shallow soil is based on limestone. This site met the criteria for an investigation of a new foliar spray designed to enhance phenolic maturity, because in warm vintages the sugar accumulation is very fast at Nagy-Eged hill, leading to alcoholic, unbalanced wines. Besides, the desired level of phenolic maturity cannot be achieved in most vintages. The trial was performed over two consecutive vintages, in 2012 and 2013.

Ten-year-old Syrah (clone ENTAV-INRA ${ }^{\circledR}$ 877) vines grafted onto Teleki $5 \mathrm{C}$ at a spacing of $2.4 \mathrm{~m} \times 0.8 \mathrm{~m}$ with a south-north row orientation were investigated. The vines were trained to a unilateral cordon at a height of $0.6 \mathrm{~m}$ and were pruned to four spurs, each bearing two nodes. A trial site of six rows was selected for each treatment (three control (unsprayed, C) and three treated (sprayed, LM) rows). Each row was divided into three blocks. One block contained 25 to 29 vines. At the same harvest time, three blocks per treatment were harvested, resulting in three replicates per treatment. The leaf spray, LalVigne ${ }^{\circledR}$ MATURE, is a formulation of $100 \%$ natural, inactivated wine yeast (Saccharomyces cerevisiae) derivatives (specifically designed to be used with the patent foliar application technology WO/2014/024039, Lallemand Inc., Canada). It is non-pathogenic, non-hazardous, food grade and non-GMO. The product is already registered in many countries and in the process of authorisation in others. Two applications of $1 \mathrm{~kg} / \mathrm{ha}$ were done. The first one was at the beginning of véraison, the second one 12 days later. The powder was diluted in water without using an adjuvant. The whole canopy was sprayed using a motorised backpack sprayer.

There were three harvest dates (2012-09-06., 2012-09-13., 2012-09-27, and 2013-09-12, 2013-09-19 and 2013-10-03) in each vintage for both the control and treated vines. Establishing as reference the commercial harvest date of the Gróf Buttler Winery, which effectively was the second harvest in our trial, the first harvest took place one week earlier and the third harvest two weeks later than the reference. One vine block represented one wine repetition per treatment at each harvest date. Véraison commenced in the first week of August in 2012, and one week later in 2013.

\section{Climatic data}

Climatic data were monitored by an automatic weather station (Boreas Ltd. Érd, Hungary), approximately 300 m from the trial site.

\section{Berry sampling}

Three sets of $20 \mathrm{~kg}$ of grapes, with each set from 25 to 29 vines, were carefully harvested by hand for both treatments at each harvest date, and transported immediately to the experimental winery. Three $1 \mathrm{~kg}$ samples from each treatment were collected at random from several clusters before vinification. The berries were selected randomly from the upper, middle and lower parts of the bunches. All the berry samples were prepared and analysed within two hours after the harvest.

For the texture analysis, 50 berries with pedicels were randomly removed from the clusters and examined visually before texture analysis. One berry represented one repetition of this measurement. Damaged berries were rejected.

A total of 150 berries were selected separately for phenolic measurements (Glories method), and these berries were subdivided into two equal groups for the $\mathrm{pH} 1$ and $\mathrm{pH}$ 3.4 solutions. The measurement was done in triplicate, and 25 berries were used for each repetition.

Three additional sets of 100 grape samples were selected for weight determination and grape composition analysis.

\section{Grape analysis}

The analytical methods recommended by the OIV (2014) were used to determine titratable acidity and the $\mathrm{pH}$ of the grapes. The sugar content (expressed as ${ }^{\circ}$ Brix) of the grape juices was determined at $20^{\circ} \mathrm{C}$, using a hand-held refractometer (Atago MASTER- $\alpha$, Japan).

\section{Assessment of grape phenolic maturity}

The phenolic potential of the grapes was calculated according to the method described by Saint-Cricq et al. (1998). This involved grinding the grapes with a blender and macerating for four hours with buffer solutions at two $\mathrm{pH}$ values (1.0 and 3.4). The original method proposed a buffer of $\mathrm{pH} \mathrm{3.2,} \mathrm{but}$ this was adjusted to 3.4 , as it is more relevant to the grapes from this region. The indices of phenolic maturity were calculated according to Glories and Augustin (1993): potential anthocyanins (A1), extractable anthocyanins (A3.4), cell maturity index (EA\%) and seed maturity index (SM\%). All the measurements were done in triplicate.

The following equations were used:

$\mathrm{EA}(\%)=[(\mathrm{A} 1-\mathrm{A} 3.4) / \mathrm{A} 1] \times 100$

$\mathrm{SM}(\%)=[(\mathrm{A} 280-((\mathrm{A} 3.4 / 1000) \times 40)) / \mathrm{A} 280] \times 100$

\section{Measurements of berry physical properties}

A TA.XTplus Texture Analyzer (Stable Micro System, Surrey, UK) with a HDP/90 platform and $30 \mathrm{~kg}$ load cell was used to follow the grape physical properties. Exponent 6.1.4.0 software was used for the data evaluation. All operative conditions were applied according to Letaief et al. (2008b) and Zsófi et al. (2014). Briefly, a P/35 probe was 
used to determine berry hardness $(\mathrm{BH})$. Berries of approximately the same size, with their pedicel attached, were gently removed from the bunch and laid on the plate of the analyser. After this, they were compressed to $25 \%$ of their diameter. The $\mathrm{P} / 2 \mathrm{~N}$ needle was applied to conduct a puncture test. A second set of berries with their pedicels were removed from the bunch, laid on the plate of the analyser and then punctured in the lateral face (Letaief et al., 2008a). The skin break force $\left(\mathrm{F}_{\mathrm{sk}}\right)$, skin break energy $\left(\mathrm{W}_{\mathrm{sk}}\right)$ and Young's modulus of berry skin $\left(\mathrm{E}_{\mathrm{sk}}\right)$ were calculated from the puncture test data using Exponent 6.1.4.0 software. Berry skin thickness $\left(\mathrm{Sp}_{\mathrm{sk}}\right)$ was measured using a $\mathrm{P} / 2$ probe with $2 \mathrm{~mm}$ diameter. For this measurement, approximately $0.25 \mathrm{~cm}^{2}$ of skin was removed from the lateral face of the berry. The skin was carefully and gently cleaned of pulp and then placed on the platform, after which the test was conducted as described by other authors previously (Letaief et al., 2008a; 2008b; Río Segade et al., 2008). The skin thickness is given by the distance (travel) between the point corresponding to the probe contact with the berry skin and the platform base during the compression test. For seed hardness tests, one seed was removed from the berry and placed on the platform on its lateral side. The seeds were crushed with the $\mathrm{P} / 35$ probe. The seed break force $\left(\mathrm{F}_{\mathrm{s}}\right)$, seed break energy $\left(\mathrm{W}_{\mathrm{s}}\right)$ and Young's modulus of the seed $\left(\mathrm{E}_{\mathrm{s}}\right)$ were also calculated using Exponent 6.1.4.0.

\section{Wine analysis}

The analytical methods recommended by the OIV (2014) were used to determine the ethanol content, titratable acidity and $\mathrm{pH}$ of the wines.

The total phenolics of the wines were analysed by the Folin-Ciocalteu method (Singleton \& Rossi, 1965) and the results expressed as gallic acid equivalents (GAE mg/L). The quantity of leuco-anthocyanins (flavan-3,4-diols) was determined as described by Flanzy et al. (1969). The bisulphite bleaching method was used to determine the anthocyanin content of the grape extracts and wines (Ribéreau-Gayon \& Stonestreet, 1965), while the total catechins (flavan-3-ols) were measured using the vanillin assay according to Amerine and Ough (1980). The colour intensity $\left(\mathrm{A}_{420}+\mathrm{A}_{520}+\mathrm{A}_{620}\right)$ and hue $\left(\mathrm{A}_{420} / \mathrm{A}_{520}\right)$ of the wines were determined using the method described by Glories (1984). Phenolic components were measured by spectrophotometer (UVmini-1240 CE UV-VIS, Shimadzu, Japan). The gelatine and $\mathrm{HCl}$ indices (Ribéreau-Gayon et al., 2006) were also calculated. All the measurements were performed in triplicate.

Qualitative and quantitative determination of resveratrol components in wines by HPLC

The analysis of the resveratrol compounds was carried out according to Kállay and Török (1997). The wine samples were filtered first on filter paper, then on a membrane of $0.45 \mu \mathrm{m}$. The eluent for the isocratic HPLC analysis consisted of a 5:5:90 mixture ( $\mathrm{v} / \mathrm{v} \%$ ) of acetonitrile:methanol:redist illed water. All the measurements were done in triplicate, and the wine samples were directly injected after filtration without dilution, in a quantity of $20 \mu \mathrm{L}$. Operating conditions and chromatograph settings were as follows: a HP Series 1050 HPLC-apparatus with a normal phase LiChrospher ${ }^{\circledR} 100 \mathrm{CN}$
(250 x 4 mm, $5 \mu \mathrm{m}$ ) column (Merck, Germany) was used for the measurements. The detector was a HP Series 1050 . The flow was set at $2 \mathrm{~mL} / \mathrm{min}$ at $30^{\circ} \mathrm{C}$ with the detection wavelength at $306 \mathrm{~nm}$. The methanol and acetonitrile used for the experiment were of HPLC grade, while other chemicals were of analytical purity. Trans-resveratrol (99\%) standard was purchased from Sigma-Aldrich (Germany). Transpiceid standard was received from the San Michele all'Adige Research and Innovation Centre. Cis-isomers were produced by UV irradiation of the trans-isomers (Sato et al., 1997). The detection limit was $0.1 \mathrm{mg} / \mathrm{L}$.

\section{Microvinification process}

Three sets of $20 \mathrm{~kg}$ of grapes were crushed, destemmed and sulphited ( $1 \mathrm{~mL}$ of $5 \%$ aqueous $\mathrm{SO}_{2}$ solution for every $1 \mathrm{~L}$ of mashed grapes) in the experimental winery at each harvest date. Macerations were conducted in $30 \mathrm{~L}$ plastic containers, and all grape repetitions were fermented separately. Three experimental wine replicates were made at each harvest time for each respective treatment. After the grapes had been processed the containers were transported immediately to the cellar to ensure constant ambient temperature $\left(13^{\circ} \mathrm{C}\right)$ from the beginning to the end of maceration. After 24 hours of cold maceration, selected active dry yeasts ( $20 \mathrm{~g}$ of dry yeast/100 $\mathrm{kg}$ of processed grapes) (Uvaferm VN, Lallemand Inc.) and yeast nutrients $(30 \mathrm{~g} / 100 \mathrm{~kg}$ of processed grapes) (Uvavital, Lallemand Inc.) were added. The maceration lasted for 23 days. The cap was punched down twice a day throughout the skin-contact period. The wines also were inoculated with 10 $\mathrm{mg} / \mathrm{L}$ lactic acid bacteria (Uvaferm Alpha, Lallemand Inc.) at the end of alcoholic fermentation. After 23 days the wines were pressed at 1.5 bar in a $30 \mathrm{~L}$ membrane press. Free-run and press wines were mixed. After malolactic fermentation had occurred, the wines were racked and transported to the laboratory for analysis. All the wines were stored at $13^{\circ} \mathrm{C}$ for several days until the moment of the analysis, and no sulphur was added prior to analysis.

\section{Sensory analysis}

All the wines were tasted by a group of 17 expert oenologists. Blind tests were carried out by comparing in pairs (control (C) vs. treated (LM)) the wines obtained from the three different harvest dates in both vintages. The wines were evaluated sensorially using the 100-point OIV (1994) method. In all the cases, the objective was for the tasters to name which wines they preferred and for what reason.

\section{Statistical analysis}

Statistical analysis was conducted using IBM SPSS 20 (IBM Corp., Armonk, NY, USA) software. Values were compared by multivariate ANOVA test with three factors (the effects of vintage: 2012, 2013, treatment: C (control), LM (LalVigne ${ }^{\circledR}$ MATURE) and harvest dates), followed by between-subject effect tests. The homogeneity of variances was checked by Levene's test. In the case of significant effect of the harvest dates, Tukey's test or the Games-Howell post hoc test was used for mean separation, according to whether or not the homogeneity of the variances held. 


\section{RESULTS}

\section{Climatic characteristics for 2012 and 2013}

Fig. 1 shows the climatic characteristics of the two vintages. The weather in 2012 can be considered as dry (total rainfall was $439.2 \mathrm{~mm}$, compared to the 50-year average of 589.6 $\mathrm{mm}$ ) and warm (average year temperature was $12.5^{\circ} \mathrm{C}$, compared to the 50 -year average of $10.7^{\circ} \mathrm{C}$ ). On the other hand, 2013 can be regarded as a cooler vintage (total rainfall: $663 \mathrm{~mm}$, average year temperature: $12.2^{\circ} \mathrm{C}$ ), although the weather was somewhat cooler with more rain during the flowering and ripening stage than in 2012.

Yield, grape juice sugar concentration, acidity, pH, berry weight, cell and seed maturity indices

The average yield per vine was $0.63 \mathrm{~kg}$ (control) and $0.65 \mathrm{~kg}$ (treated) in 2012, and $0.99 \mathrm{~kg}$ (control) and $0.92 \mathrm{~kg}$ (treated) in 2013. An average of seven bunches were grown per vine in both years.

Table 1 shows the standard grape juice parameters. The grapes reached a greater level of technological maturity in 2012 (maximum sugar concentration: $24.3^{\circ}$ Brix) compared to 2013 (maximum sugar concentration: $21.2^{\circ} \mathrm{Brix}$ ). Indeed, the berry sugar concentration in 2012 exceeded that of 2013 by 15 to $25 \%$. There also were notable differences in the case of titratable acidity, with the values in 2013 being significantly higher. The lowest concentration was $8.6 \mathrm{~g} / \mathrm{L}$. The weight loss of the berries during ripening was due to dehydration. There was some rain between the second and the third harvest dates in 2012, however, which resulted in heavier berries. Clearly, the vintage had a very strong effect on all the parameters, as can be seen in Table 1 .

The Glories indices, which provide a prediction of phenolic compounds in the resulting wines (Kontoudakis et al., 2010) are given in Table 2. In general, the lower the $\mathrm{EA} \%$ and $\mathrm{SM} \%$ values, the riper the berry. In most cases the regular range for $\mathrm{A} 1, \mathrm{EA} \%$ and $\mathrm{SM} \%$ varied between 500 to $2000 \mathrm{mg} / \mathrm{L}, 70 \%$ to $20 \%$ and $60 \%$ to $0 \%$ respectively (Ribéreau-Gayon et al., 2006). The A1 and A3.4 values indicate a good anthocyanin concentration, especially in 2012. Interestingly, the EA\% values showed an increase in some cases during ripening, implying that the extractability of the anthocyanins decreased. None of the factors affected the seed maturity index (SM\%).

\section{Grape texture properties}

Table 3 shows the texture parameters of the berries. The berries became softer $(\mathrm{BH})$ during ripening. The significant increase observable in 2012 was due to the rainfall during
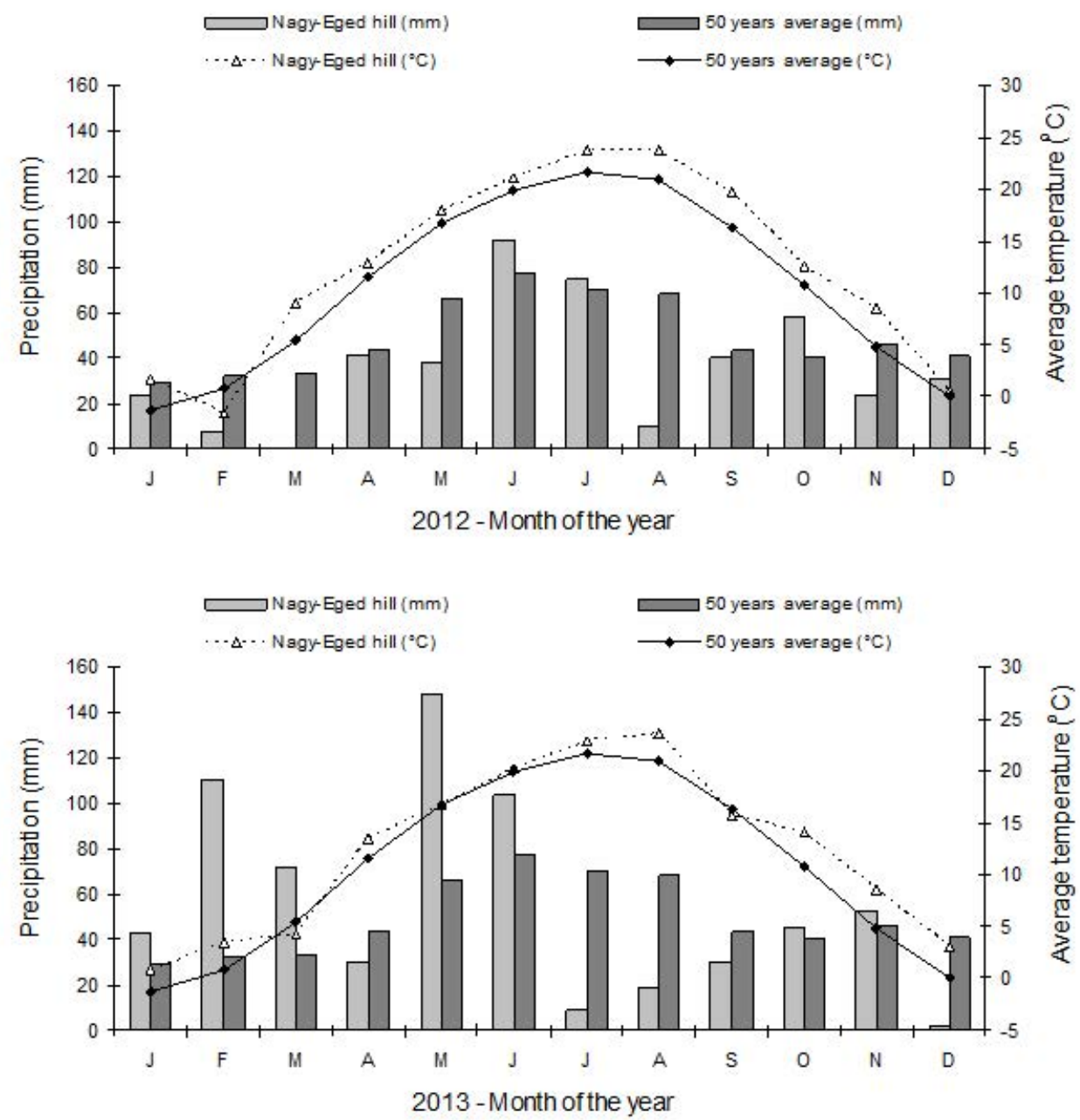

FIGURE 1

Average air temperature (lines) and monthly sum of precipitation (bars) for 2012 and 2013 at the experimental site (data from automatic weather stations). 


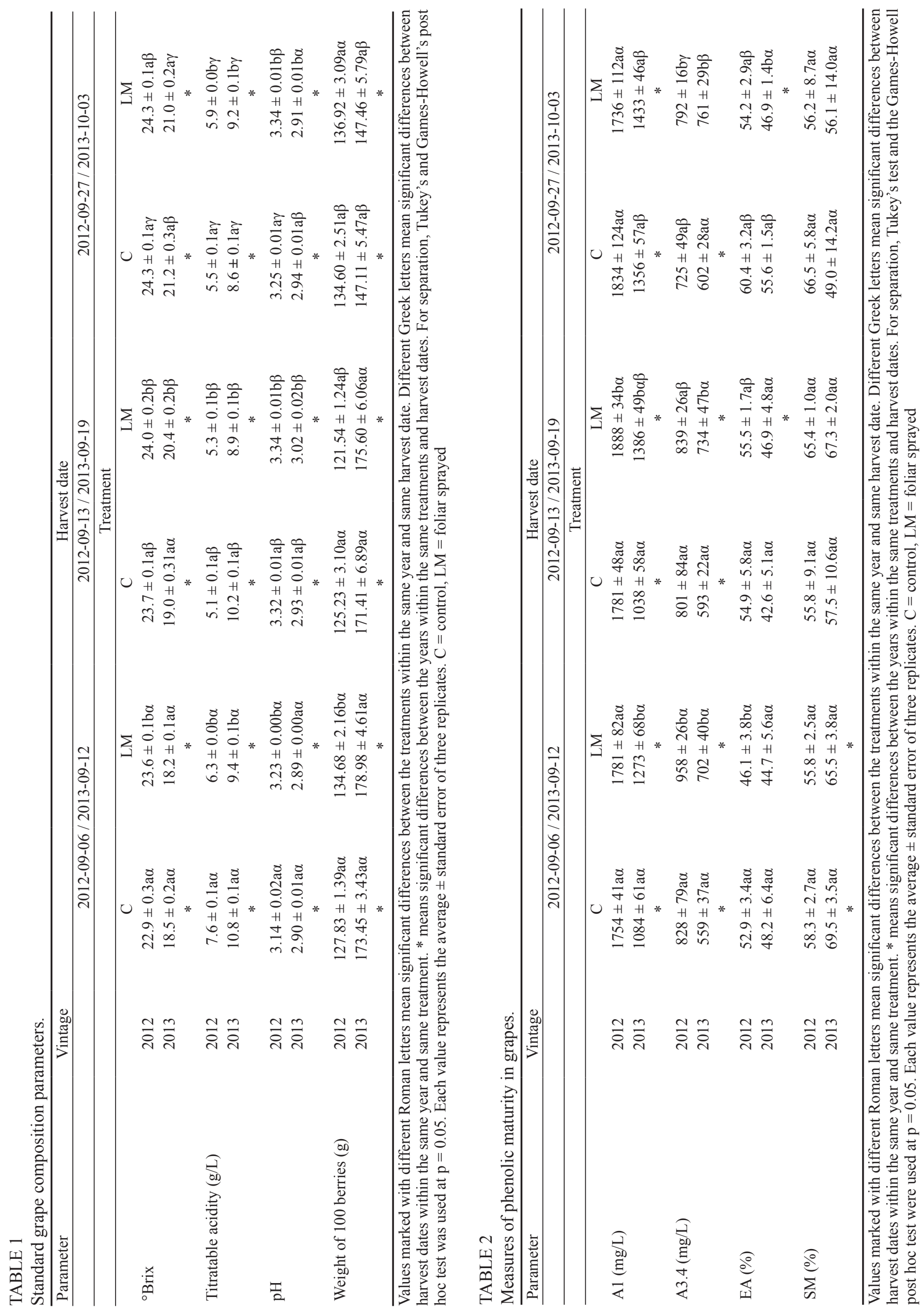




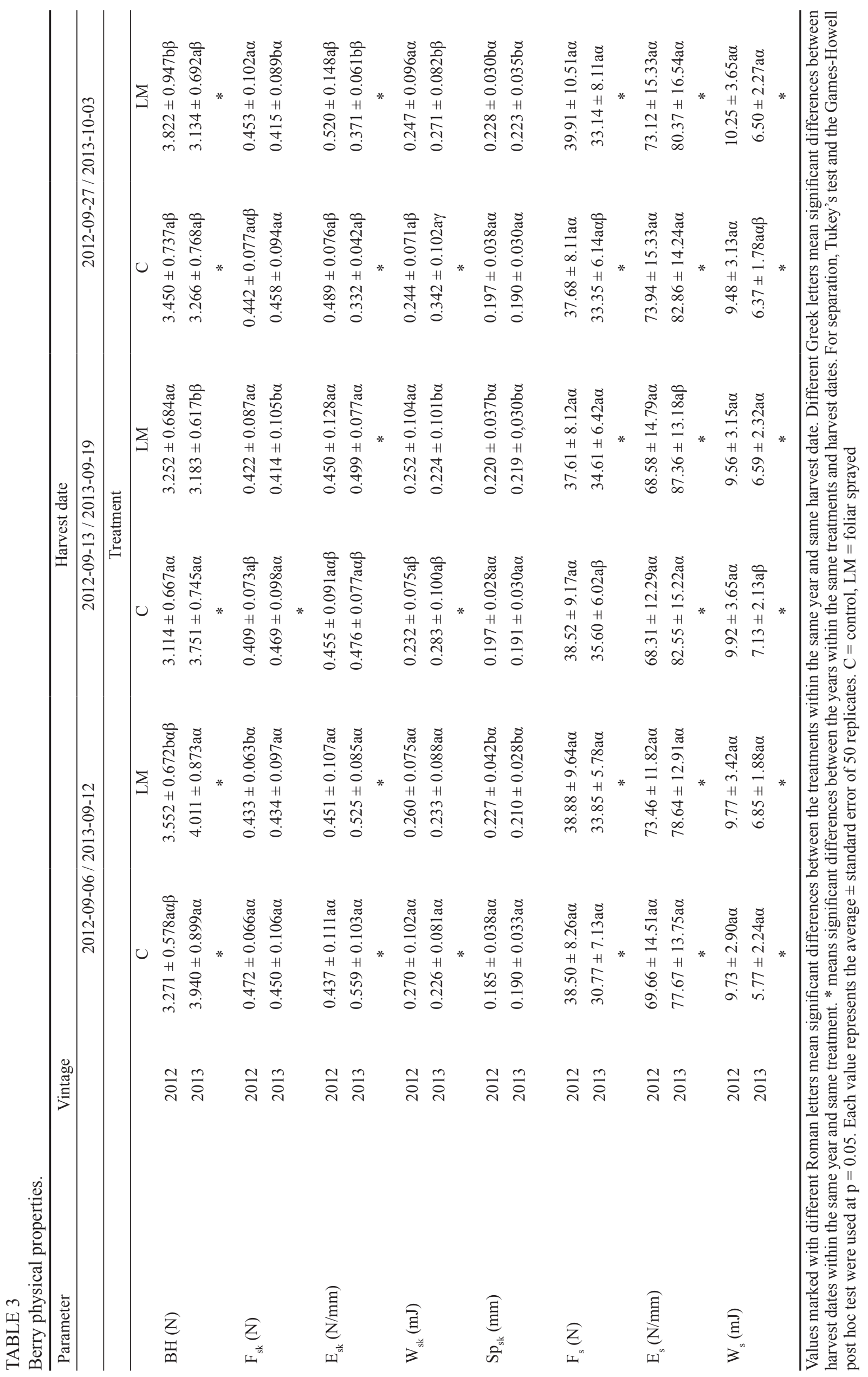


the second and third harvest periods. Changes in skin break force $\left(\mathrm{F}_{\mathrm{sk}}\right)$ showed a very similar pattern to $\mathrm{W}_{\mathrm{sk}}$ related to the treatments and the harvest time. The impact of the leaf spray caused a significant increase in skin thickness $\left(\mathrm{Sp}_{\mathrm{sk}}\right)$. The values were above $0.2 \mathrm{~mm}$ in the case of the treated grapes at all harvest dates and in both years. There was no correlation between skin thickness $\left(\mathrm{Sp}_{\mathrm{sk}}\right)$ and skin break force $\left(\mathrm{F}_{\mathrm{sk}}\right)$ values. The seed texture parameters remained unchanged, despite the treatment between the harvest dates. However, the vintage had a very strong effect on these parameters.

\section{Wine composition}

Table 4 summarises the main wine parameters. The wines had a wide range of alcohol concentration (between $11.28 \%$ $\mathrm{v} / \mathrm{v}$ and $15.55 \% \mathrm{v} / \mathrm{v})$. However, the foliar spray did not influence this parameter. We found significant differences between the titratable acidity and $\mathrm{pH}$ in the first phase of ripening, but the differences were no longer significant by the second and third harvest dates.

The total polyphenol values were independent of the foliar spray treatment. In 2012 we measured significantly higher (above $2000 \mathrm{mg} / \mathrm{L}$ ) values than in 2013 (concentration between 1025 and $1304 \mathrm{mg} / \mathrm{L}$ ). The leuco-anthocyanin and anthocyanin concentrations were found to be significantly higher in the treated wines in three instances: at the second and the third harvest dates in 2012, and at the second harvest date in 2013 (although only for anthocyanins). The weather conditions in 2012 favoured anthocyanin synthesis up to $796 \mathrm{mg} / \mathrm{L}$. By contrast, the unfavourable vintage in 2013 resulted in a significantly lower anthocyanin concentration (Table 4). The impact of the foliar spray and harvest date on catechin levels is unclear. The colour intensity $\left(\mathrm{A}_{420}+\mathrm{A}_{520}\right.$ $+\mathrm{A}_{620}$ ) correlated well with the increasing concentration of anthocyanins. The values of colour hue $\left(\mathrm{A}_{420} / \mathrm{A}_{520}\right)$ represent a bluish tone, but this is typical for young red wines (Boulton, 2001).

The gelatine index increased significantly between the first and the third harvest dates in the foliar spray-treated grapes in 2012. In 2013 the differences between harvest dates were smaller, and the values also were much lower than in 2012 and less than the optimal value due to the unfavourable weather conditions (Ribéreau-Gayon et al., 2006). During tastings the wines were characterised by green, unripe tannins. $\mathrm{HCl}$ indices showed a marked variation, from 4.34 to 12.99. The foliar spray treatment increased this parameter, but the difference was significant only at the second harvest date in 2012, and at the third harvest date in 2013.

Table 5 shows the changes in resveratrol concentration in the wines. The majority of resveratrol was found in the wines as the isomeric forms of piceid (resveratrol glycoside). In 2012 and 2013, cis- and trans-resveratrol were not detected in the control wines at the first harvest date. Trans-resveratrol was also absent in the treated wines at the second harvest date in 2013. Treated wines contained this compound from the first harvest date. Under the effect of the foliar spray, total resveratrol concentration increased especially in the first phase of ripening. The differences in total resveratrol concentration were not significant in three cases: at the second harvest dates in both years, and at the third harvest date in 2012.

\section{Sensory analysis}

All the tasters were able to differentiate between the control and the treated wines. Wines made from foliar spray-treated grapes were preferred and received higher scores than the controls (data not shown). Vintage had a very strong effect on the sensory quality. In 2013 the average points were much lower for all the wines, but the positive impact of the foliar spray remained sensible.

\section{DISCUSSION}

The foliar spray treatment had a significant effect on the titratable acidity and $\mathrm{pH}$ of the grapes, with the treated berries containing less acid. This is probably due to the higher berry respiration as an effect of faster ripening (Sweetman et al., 2009). There was a positive effect of the leaf spray treatment on both total (A1) and potential (A3.4) anthocyanins, favouring their accumulation in both years and at nearly all harvest dates. Several phenomena may generally trigger the higher anthocyanin concentration of the wines. These include a beneficial change in the berry skin/flesh ratio (Kennedy et al., 2002; Ojeda et al., 2002), increased extractability (Río Segade et al., 2011) and intensive anthocyanin synthesis (Downey et al., 2004; Yamane et al., 2006; Koshita et al., 2011). In addition, during anthocyanin extraction in winemaking it also is necessary to take into account the changes in grape skin cell wall composition and structure, because this can modify the extractability (Hanlin et al., 2010). The foliar spray-treated grapes reached a greater level of phenolic maturity in both years, as can be seen in the results for the first and third harvests (values of EA (\%) are lower; see Table 3). The absolute (A1) and extractable pigment (A3.4) concentration were also higher due to the foliar spray in both years, except for one instance in 2012. At the third harvest date the treated grapes had a lower A1 value. Vintage had a significant influence on all the Glories parameters except for SM\%. As can be seen from the data in Table 2, SM\% values did not match the optimal criteria (Ribéreau-Gayon et al., 2006) for ripeness in several cases. Values higher than $60 \%$ mean that the seeds were not sufficiently ripe, and thus a long fermentation maceration would not be recommended. Neither the vintage, nor the foliar spray treatment, affected the SM\% values significantly.

The foliar spray resulted in a significant increase in berry skin thickness $\left(\mathrm{S}_{\mathrm{psk}}\right)$ at all sampling dates. The harvest date and the vintage did not influence the skin thickness significantly. The skin hardness $\left(\mathrm{F}_{\mathrm{sk}}\right)$ values were significant lower for the treated grapes in three cases (first harvest date in 2012, second and third harvest dates in 2013). Our results show that the concentration of anthocyanins was higher in the thicker skins and also in the case of lower skin hardness $\left(\mathrm{F}_{\mathrm{sk}}\right)$. This is the opposite of other findings, where thinner (Río Segade et al., 2011) and harder skins (Rolle et al., 2008; 2009) contained more anthocyanins. However, thicker and softer skins may also contain more anthocyanins due to the increased flavonoid synthesis and higher berry skin/flesh ratio. The enhanced pigment accumulation due to the foliar spray is also supported by Duo et al. (2014) and Lissarrague et al. (2014). Berry texture parameters were strongly modified by vintage effect, as seen before (Letaief et al., 2008a; Río Segade et al., 2008). Young's modulus of berry skin ( $\left.\mathrm{E}_{\mathrm{sk}}\right)$, 


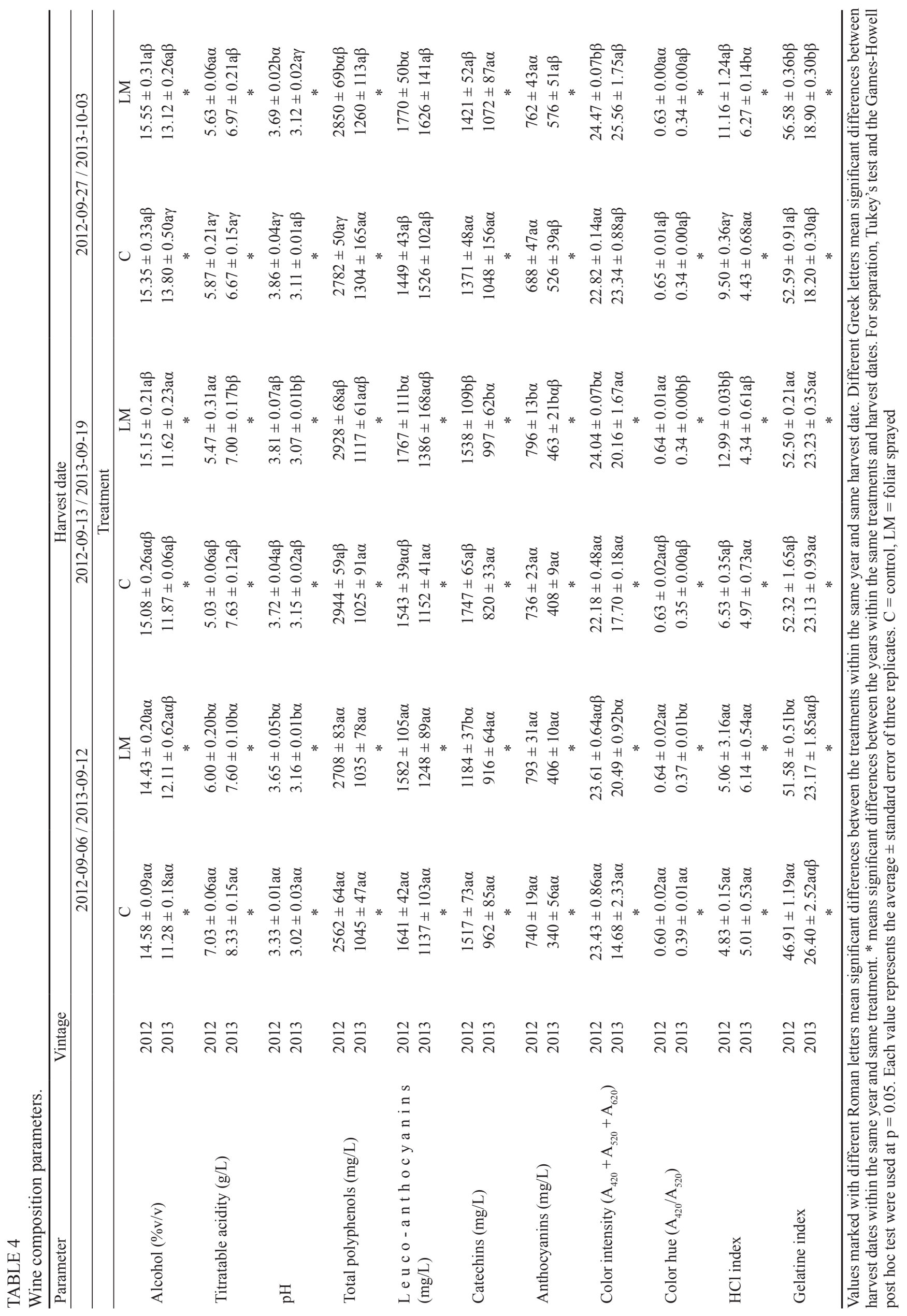




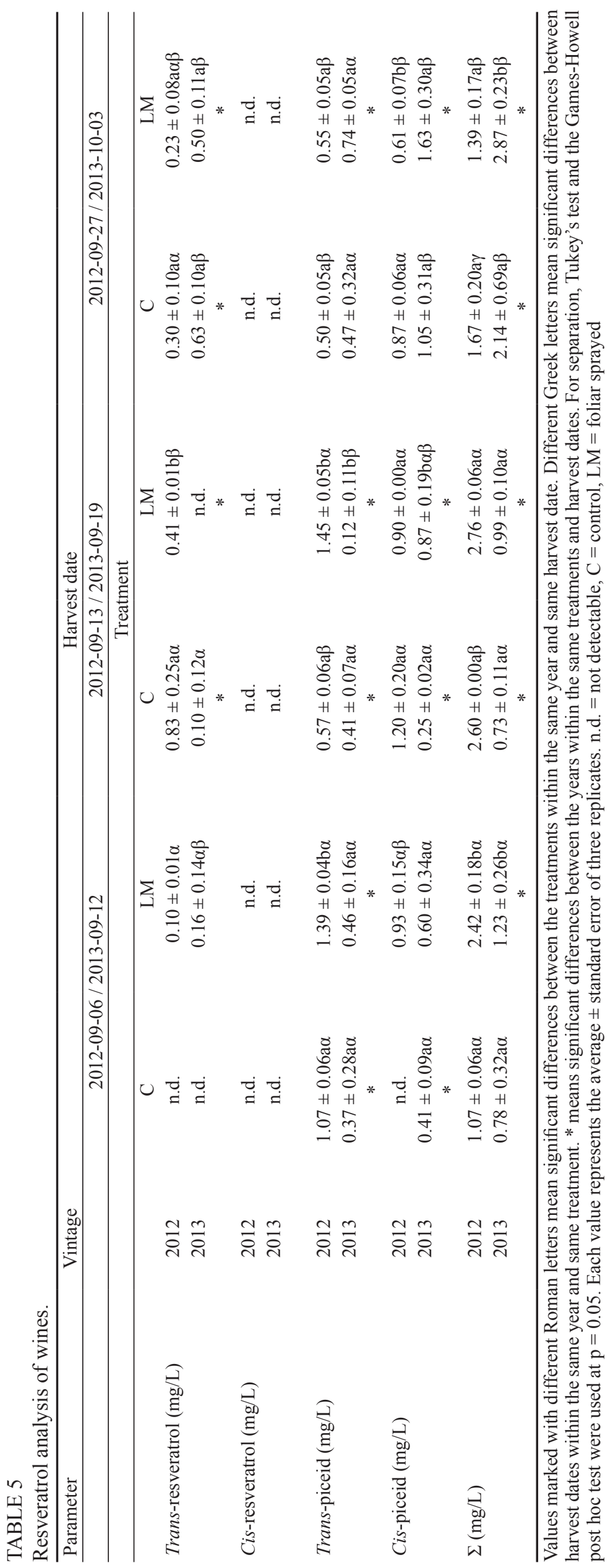


berry hardness $(\mathrm{BH})$ and seed texture properties were the mostly affected parameters, as can be seen in Table 3. It seems that cooler weather results in harder skin and softer seeds. In 2012 the seeds were harder than in 2013. In 2013 the $\mathrm{F}_{\mathrm{s}}$ values remained under $36 \mathrm{~N}$, and the values of work needed for the break $\left(\mathrm{W}_{\mathrm{s}}\right)$ were under $6 \mathrm{~mJ}$, indicating softer seeds. There was no difference in seed texture parameters $\left(\mathrm{F}_{\mathrm{s}}\right.$, $\mathrm{E}_{\mathrm{s}}, \mathrm{W}_{\mathrm{s}}$ ) between the control and treated berries. Furthermore, the harvest date had no effect on these parameters.

Torchio et al. (2010) reported a decreasing Young's modulus of the berry skin $\left(\mathrm{E}_{\mathrm{sk}}\right)$ as ripening progressed. This was observed only in the 2013 season and can most probably be explained by the combined effects of changes in the cell wall structure, ripening processes and the water content of the berries. With respect to other berry physical properties, only the $\mathrm{BH}$ values, which reflect berry softness, decreased with ripening - as expected. The only increase in $\mathrm{BH}$ values (Table 3 ) can be seen between the second and third harvest dates in 2012 due to a rainy period at that time.

The increased values of $\mathrm{HCl}$ and gelatine indices for the wines from foliar spray-treated grapes in 2012, and to some extent in 2013, indicate a more polymerised and balanced tannin structure compared to the control wines. The sensory analysis supported these facts. All the tasters were able to differentiate between the control and treated wines. The wines made from foliar spray-treated grapes had more intense flavour, better mouthfeel, higher varietal character and a longer finish. In all cases the tasters preferred wines made from treated grapes. This capacity to achieve a higher phenolic maturity is a potential benefit of the foliar spray treatment. Interestingly, there was a lower concentration of monomeric catechins in wines from the foliar spray-treated grapes in 2012. This observation may be explained by the higher polymerised phenolic compound concentration. The $\mathrm{HCl}$ indices of the wines were between 4 and 12 . A wine suitable for aging has a value of 10 to 25 (Ribéreau-Gayon et al., 2006). Only two wines met this criterion. Both wines were made from foliar spray-treated grapes at the second and third harvest dates in 2012.

Resveratrol synthesis was also positively affected by the foliar spray, especially in the first phase of ripening. However, the differences disappeared by the second harvest in both vintages. A significantly higher concentration was found for the first treated wines in both vintages and for the third treated wine in 2013. The causes may be the same as in the case of the higher anthocyanin concentration, since resveratrol can also be found in the berry skins. Vintage strongly affected the amount of total resveratrol. It seems the lower average temperature during the ripening phase (Fig. 1) delays stilbene synthesis. The cooler vintage in 2103 also reduced the impact of the foliar spray, resulting in a lower resveratrol concentration at the first harvest date. Transpiceid was the most abundant stilbene compound. This is in accordance with other findings (Bavaresco et al., 2007).

The observed changes (the treated berries had higher anthocyanin content along with thicker skins) could be explained by vine-pathogen interaction. Vines recognise the yeasts in the foliar spray, which activates some defence mechanisms (Langcake \& Pryce, 1976; Hahn, 1996; Garcia-
Brugger et al., 2006; Santamaria et al., 2011). In this way, secondary metabolism is enhanced in the berries (Zhao et al., 2005).

Overall, it seems that the impact of the foliar spray was stronger in the earlier phases of the grape-ripening process. As the ripening went forward the differences decreased between the treatments, while remaining noticeable until the end of the ripening.

\section{CONCLUSION}

We examined the impacts of the application of yeast derivatives (LalVigne ${ }^{\circledR}$ MATURE, Lallemand Inc.) on Syrah grape phenolic maturity as well as on wine phenolic composition and concentration. The results from two vintages indicate that its application led to more optimal harvest conditions. In addition, a higher level of phenolic maturity was achieved in both warm (2012) and cool (2013) vintages. The application of this foliar spray results in wines that are more balanced, and showing more flavours and complexity than the ones made from unsprayed vines. Preliminary evidence was also obtained to suggest that LalVigne ${ }^{\circledR}$ MATURE may help in cooler and less optimal vintages by enhancing the ripening process, leading to wines with greater oenological potential. Moreover, thicker grape skins and accumulation of resveratrol in the early phases could play an important role in plant protection.

\section{LITERATURE CITED}

Amerine, M.A. \& Ough, C.S., 1980. Methods for analysis of musts and wines. Wiley, New York.

Bavaresco, L., 2003. Role of viticultural factors on stilbene concentrations of grapes and wine. Drugs Exp. Clin. Res. 29, 181-187.

Bavaresco, L., Pezzutto, S., Gatti, M. \& Mattivi, F., 2007. Role of the variety and some environmental factors on grape stilbenes. Vitis 46, 57-61.

Boulton, R. 2001. The copigmentation of anthocyanins and its role in the color of red wine: A critical review. Am. J. Enol. Vitic. 52, 67-87.

Bruwer, J., Saliba, A. \& Miller, B., 2011. Consumer behaviour and sensory preference differences: implications for wine product marketing. J. Consum. Mark. 28, 5-18.

Downey, M.O., Harvey, J.S. \& Robinson, S.P., 2004. The effect of bunch shading on berry development and flavonoid accumulation in Shiraz grapes. Aust. J. Grape Wine Res. 10, 55-73.

Duo, A., Souquet, J.M., Samson, A., Caille, S., Silvano, A., Suárez, C. \& Ojeda, H., 2014. Elicitors and water stress. Effect on Syrah grapes \& wine quality cultivated in Gruissan, France. In Jean-Marie, A. (ed.). Proc. $37^{\text {th }}$ World Congr. Vine \& Wine \& $12^{\text {th }}$ Gen. Assem. of the OIV Book of Abstracts., November 2014, Mendoza, Argentina. pp. 466 - 467.

Flanzy, M., Aubert, S. \& Marinos, M., 1969. New technique for determination of leucoanthocyanic tannins. Appl. Ann. Technol. Agric. 18, $327-328$.

Garcia-Brugger, A., Lamotte, O., Vandelle, E., Bourque, S., Lecourieux, D., Poinssot, B., Wendehenne, D. \& Pugin, A., 2006. Early signaling events induced by elicitors of plant defenses. Mol. Plant Microbe Interact. 19, 71124.

Gatti, M., Bernizzoni, F., Civardi, S. \& Poni, S., 2012. Effects of cluster thinning and pre-flowering leaf removal on growth and grape composition in cv. Sangiovese. Am. J. Enol. Vitic. 63, 325-332. 
Glories, Y. 1984. La couleur des vins rouges II. Mesure, origine et interpretation. Connaissance Vigne Vin 18, 253-271.

Glories, Y. \& Augustin, M., 1993. Maturité phénolique du raisin, conséquences technologiques: Applications aux millésimes 1991 et 1992 In Proc. Actes du Colloque Journée Technique du CIVB, pp. 56 - 61.

Guidoni, S., Allara, P. \& Schubert, A., 2002. Effect of cluster thinning on berry skin anthocyanin composition of Vitis vinifera cv. Nebbiolo. Am. J. Enol. Vitic. 53, 224-226.

Hahn, M.G. 1996. Microbial elicitors and their receptors in plants. Annu. Rev. Phytopathol. 34, 387-412.

Hanlin, R.L., Hrmova, M., Harbertson, J.F. \& Downey, M.O., 2010. Review: Condensed tannin and grape cell wall interactions and their impact on tannin extractability into wine. Aust. J. Grape Wine Res. 16, 173-188.

Hannah, L., Roehrdanz, P.R., Ikegami, M., Shepard, A.V., Shaw, M.R., Tabor, G., Zhi, L., Marquet, P.A. \& Hijmans, R.J., 2013. Climate change, wine, and conservation. Proc. Natl. Acad. Sci. U.S.A. 110, 6907-6912.

Jackson, D.I. \& Lombard, P.B., 1993. Environmental and management practices affecting grape composition and wine quality - A review. Am. J. Enol. Vitic. 44, 409-430.

Jeandet, P., Bessis, R., Sbaghi, M., Meunier, P. \& Trollat, P. 1995. Resveratro content of wines of different ages: Relationship with fungal disease pressure in the vineyard. Am. J. Enol. Vitic. 46, 1-4.

Jones, G.V., White, M.A., Cooper, O.R. \& Storchmann, K., 2005. Climate change and global wine quality. Climatic Change 73, 319-343.

Kállay, M. \& Török, Z., 1997. Determination of resveratrol isomers in Hungarian wines. Kert. Tud. 29, 78-82.

Kemp, B.S., Harrison, R. \& Creasy, G.L., 2011. Effect of mechanical leaf removal and its timing on flavan-3-ol composition and concentrations in Vitis vinifera L. cv. Pinot noir wine. Aust. J. Grape Wine Res. 17, 270-279.

Kennedy, J.A., Matthews, M.A. \& Waterhouse, A.L., 2002. Effect of maturity and vine water status on grape skin and wine flavonoids. Am. J. Enol. Vitic. 53, 268-274.

Kontoudakis, N., Esteruelas, M., Fort, F., Canals, J.M. \& Zamora, F., 2010. Comparison of methods for estimating phenolic maturity in grapes: Correlation between predicted and obtained parameters. Anal. Chim. Acta $660,127-133$

Koshita, Y., Yamane, T., Yakushiji, H., Azuma, A. \& Mitani, N., 2011. Regulation of skin color in 'Aki Queen' grapes: Interactive effects of temperature, girdling, and leaf shading treatments on coloration and total soluble solids. Sci. Hortic. 129, 98-101.

Langcake, P. \& Pryce, R.J., 1976. The production of resveratrol by Vitis vinifera and other members of the Vitaceae as a response to infection or injury. Physiol. Plant Pathol. 9, 77-86.

Lee, J. \& Skinkis, P.A., 2013. Oregon 'Pinot noir' grape anthocyanin enhancement by early leaf removal. Food Chem. 139, 893-901.

Letaief, H., Rolle, L. \& Gerbi, V., 2008a. Mechanical behavior of winegrapes under compression tests. Am. J. Enol. Vitic. 59, 323-329.

Letaief, H., Rolle, L., Zeppa, G. \& Gerbi, V., 2008b. Assessment of grape skin hardness by a puncture test. J. Sci. Food Agric. 88, 1567-1575.

Lissarrague, J.R., Téllez, J., García, E. \& Peiro, E., 2014. Impact on agronomic parameters in vines and wine quality of foliar treatments with specific fractions of yeast derivatives. In Proc. $65^{\text {th }}$ ASEV Nat. Conf. $\& 39^{\text {th }}$ ASEV Eastern Section Ann. Meet. Techn., Hyatt Regency Austin, Austin, Texas, USA, July 2014. Abstracts. American Society for Enology and Viticulture. p. 121.
OIV. 1994. Normes des concours internationaux des vins. Bulletin de l'OIV 67, 558-597.

OIV. 2014. Compendium of international methods of wine and must analysis vol. 1. OIV, Paris.

Ojeda, H., Andary, C., Kraeva, E., Carbonneau, A. \& Deloire, A. 2002. Influence of pre- and postveraison water deficit on synthesis and concentration of skin phenolic compounds during berry growth of Vitis vinifera cv. Shiraz. Am. J. Enol. Vitic. 53, 261-267.

Poni, S., Casalini, L., Bernizzoni, F., Civardi, S. \& Intrieri, C., 2006. Effects of early defoliation on shoot photosynthesis, yield components, and grape composition. Am. J. Enol. Vitic. 57, 397-407.

Poni, S., Bernizzoni, F., Civardi, S. \& Libelli, N., 2009. Effects of prebloom leaf removal on growth of berry tissues and must composition in two red Vitis vinifera L. cultivars. Aust. J. Grape Wine Res. 15, 185-193.

Prajitna, A., Dami, I.E., Steiner, T.E., Ferree, D.C., Scheerens, J.C. \& Schwartz, S.J., 2007. Influence of cluster thinning on phenolic composition, resveratrol, and antioxidant capacity in Chambourcin wine. Am. J. Enol. Vitic. 58, 346-350.

Ribéreau-Gayon, P. \& Stonestreet, E., 1965. Le dosage des anthocyanes dans le vin rouge. Bull. Soc. Chim. Fr. 9, 2649-2652.

Ribéreau-Gayon, P., Glories, Y., Maujean, A. \& Dubourdieu, D., 2006. Handbook of enology, vol. 2: The chemistry of wine and stabilization and treatments. Wiley, New York.

Río Segade, S., Rolle, L., Gerbi, V. \& Orriols, I., 2008. Phenolic ripeness assessment of grape skin by texture analysis. J. Food Comp. Anal. 21, 644649.

Río Segade, S., Giacosa, S., Gerbi, V. \& Rolle, L., 2011. Berry skin thickness as main texture parameter to predict anthocyanin extractability in winegrapes. LWT-Food Sci. Technol. 44, 392-398.

Rolle, L., Torchio, F., Zeppa, G. \& Gerbi, V., 2008. Anthocyanin extractability assessment of grape skins by texture analysis. J. Int. Sci. Vigne Vin. 42, 157-162.

Rolle, L., Torchio, F., Zeppa, G. \& Gerbi, V., 2009. Relationship between skin break force and anthocyanin extractability at different ripening stages. Am. J. Enol. Vitic. 60, 93-97.

Saint-Cricq, N., Vivas, N. \& Glories, Y., 1998. Maturité phénolique: définition et contrôle. Rev. Fr. Oenol. 173, 22-25.

Santamaria, A.R., Mulinacci, N., Valletta, A., Innocenti, M. \& Pasqua, G., 2011. Effects of elicitors on the production of resveratrol and viniferins in cell cultures of Vitis vinifera L. cv Italia. J. Agric. Food Chem. 59, 90949101

Sato, M., Suzuki, Y., Okuda, T. \& Yokotsuka, K., 1997. Contents of resveratrol, piceid, and their isomers in commercially available wines made from grapes cultivated in Japan. Biosci. Biotechnol. Biochem. 61, 18001805 .

Schultz, H.R. 2000. Climate change and viticulture: A European perspective on climatology, carbon dioxide and UV-B effects. Aust. J. Grape Wine Res. 6, 2-12.

Singh Brar, H., Singh, Z., Swinny, E. \& Cameron, I., 2008. Girdling and grapevine leafroll associated viruses affect berry weight, colour development and accumulation of anthocyanins in 'Crimson Seedless' grapes during maturation and ripening. Plant Sci. 175, 885-897.

Singleton, V.L. \& Rossi, J.A., 1965. Colorimetry of total phenolics with phosphomolybdic-phosphotungstic acid reagents. Am. J. Enol. Vitic. 16, 144-158. 
Sweetman, C., Deluc, L.G., Cramer, G.R., Ford, C.M. \& Soole, K.L., 2009. Regulation of malate metabolism in grape berry and other developing fruits. Phytochem. 70, 1329-1344.

Torchio, F., Cagnasso, E., Gerbi, V. \& Rolle, L., 2010. Mechanical properties, phenolic composition and extractability indices of Barbera grapes of different soluble solids contents from several growing areas. Anal. Chim. Acta 660, 183-189.

Vezzulli, S., Civardi, S., Ferrari, F. \& Bavaresco, L., 2007. Methyl jasmonate treatment as a trigger of resveratrol synthesis in cultivated grapevine. Am. J. Enol. Vitic. 58, 530-533.
Yamane, T., Jeong, S.T., Goto-Yamamoto, N., Koshita, Y. \& Kobayashi, S., 2006. Effects of temperature on anthocyanin biosynthesis in grape berry skins. Am. J. Enol. Vitic. 57, 54-59.

Zhao, J., Davis, L.C. \& Verpoorte, R., 2005. Elicitor signal transduction leading to production of plant secondary metabolites. Biotechnol. Adv. 23, 283-333.

Zsófi, Z., Villangó, S., Pálfi, Z., Tóth, E. \& Bálo, B., 2014. Texture characteristics of the grape berry skin and seed (Vitis vinifera L. cv. Kékfrankos) under postveraison water deficit. Sci. Hortic. 172, 176-182. 